\title{
The Shīi ${ }^{-1}$ Past in the Great Book of the Songs
}

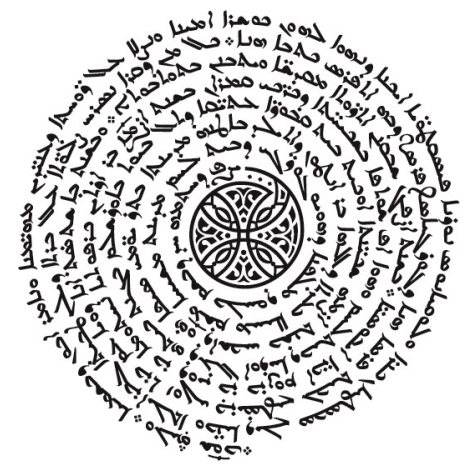




\section{Islamic History and Thought}

\section{Series Editorial Board}

$\begin{aligned} \text { Peter Adamson } & \text { Jack Tannous } \\ \text { Beatrice Gründler } & \text { Isabel Toral-Niehoff } \\ \text { Ahmad Khan } & \text { Manolis Ulbricht }\end{aligned}$

\section{Advisory Editorial Board}

$\begin{aligned} \text { Binyamin Abrahamov } & \text { Konrad Hirschler } \\ \text { Asad Q. Ahmed } & \text { James Howard-Johnston } \\ \text { Mehmetcan Akpinar } & \text { Maher Jarrar } \\ \text { Abdulhadi Alajmi } & \text { Marcus Milwright } \\ \text { Mohammad-Ali Amir-Moezzi } & \text { Harry Munt } \\ \text { Arezou Azad } & \text { Gabriel Said Reynolds } \\ \text { Godefroid de Callatay } & \text { Walid A. Saleh } \\ \text { Maria Conterno } & \text { Jens Scheiner } \\ \text { Farhad Daftary } & \text { Delfina Serrano } \\ \text { Wael Hallaq } & \text { Georges Tamer }\end{aligned}$

Islamic History and Thought provides a platform for scholarly research on any geographic area within the expansive Islamic world, stretching from the Mediterranean to China, and dated to any period from the eve of Islam until the early modern era. This series contains original monographs, translations (Arabic, Persian, Syriac, Greek, and Latin) and edited volumes. 


\section{The Shī'ī Past \\ in the Great Book of the Songs}

A New Perspective on the Kitäb al-Aghäni

by Abū al-Faraj al-Ișfahānī and Shî ${ }^{\prime} \overline{1}$ Islam in the Tenth Century

\section{I-Wen Su}

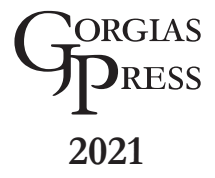


Gorgias Press LLC, 954 River Road, Piscataway, NJ, 08854, USA

www.gorgiaspress.com

Copyright (C) 2021 by Gorgias Press LLC

All rights reserved under International and Pan-American Copyright Conventions. No part of this publication may be reproduced, stored in a retrieval system or transmitted in any form or by any means, electronic, mechanical, photocopying, recording, scanning or otherwise without the prior written permission of Gorgias Press LLC.

2021

$$
\kappa
$$

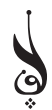

ISBN 978-1-4632-0714-4

ISSN 2643-6906

\section{Library of Congress Cataloging-in-Publication Data}

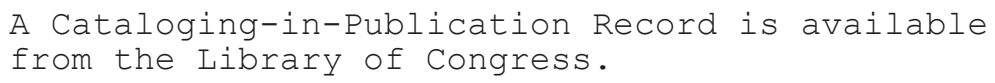

Printed in the United States of America 
For Ai-Yun Sheng, Jo Hsu, Sunny Tsai, and SPP-four extraordinary and, verily, extra-ordinary ladies in my life 
